\title{
AGENDA RISET PRIORITAS TENTANG KOMERSIALISASI RUANG TERBUKA HIJAU PUBLIK DAN KAITANNYA DENGAN PANDEMI COVID-19
}

\section{PRIORITY RESEARCH AGENDA ON THE COMMERCIALIZATION OF PUBLIC GREEN OPEN SPACE AND ITS RELATIONSHIP WITH THE COVID-19 PANDEMIC}

\author{
Sylvia Agustina ', Desi Safriana ${ }^{2}$, Jannata Ardesir ${ }^{3}$, Rifani Nasron 4 \\ 1Universitas Syiah Kuala; Jln. Teuku Nyak Arief Darussalam, Banda Aceh, Aceh, 23111; sylvia_agustina@unsyiah.ac.id \\ ${ }^{2}$ Universitas Islam Negeri Ar-Raniry; Jl. Syeikh Abdul Rauf Darussalam Banda Aceh, 23111; desisafriana@ar-raniry.ac.id \\ 3 Universitas Syiah Kuala; Jln. Teuku Nyak Arief Darussalam, Banda Aceh, Aceh, 23111; jannata@mhs.unsyiah.ac.id \\ 4Universitas Syiah Kuala; Jln. Teuku Nyak Arief Darussalam, Banda Aceh, Aceh, 23111; faninasron@mhs.unsyiah.ac.id
}

Info Artikel:

\begin{abstract}
ABSTRAK
Undang-Undang Tata Ruang Republik Indonesia mensyaratkan ketersediaan ruang terbuka hijau (RTH) kota sebesar 30\%. Di tengah upaya memenuhi target tersebut justru terjadi penggunaan RTH secara komersial yang berpotensi mengurangi luas efektif yang digunakan untuk publik dan mempengaruhi kuantitas ruang, serta kualitas interaksi warga dengan RTH. Penelitian ini bertujuan untuk mengidentifikasi tipe dan tingkat komersialisasi RTH publik di Banda Aceh, mengidentifikasi tema riset terkait dengan komersialisasi RTH, dan merumuskan skala prioritas untuk kajian lebih lanjut dengan mempertimbangkan kondisi pandemi covid-19. Penelitian dilakukan melalui diskusi kelompok terarah, observasi lapangan, wawancara dan penjaringan pendapat. Hasil penelitian awal di Banda Aceh menunjukkan bahwa kegiatan komersial berpotensi merubah RTH publik menjadi kuasi-publik. Kehadiran multi aktor dalam pengelolaan kegiatan komersial dalam RTH dapat menjadi suatu sinergi, namun dapat pula menjadi kontestasi. Dampak penurunan kunjungan dan intensitas kegiatan komersial terjadi pada masa awal pandemi namun kembali meningkat sehingga diperlukan penanganan khusus. Fokus riset terkait pemanfaatan RTH sebagai alternatif ruang interaksi khususnya pada masa pandemi perlu dirumuskan dengan pendekatan lintas disiplin. Agenda riset prioritas yang berhasil diidentifikasi adalah yang berkarakter penelitian terapan yaitu pemetaan lengkap RTH yang terdampak kegiatan komersial serta penerapan zonasi mikro untuk pengendalian pemanfaatan ruang dalam RTH, termasuk untuk memitigasi potensi penyebaran wabah covid-19.
\end{abstract}

Kata Kunci: ruang terbuka hijau publik; komersialisasi; agenda riset; pandemi

\begin{abstract}
The Spatial Planning Law of the Republic of Indonesia requires cities to provide a minimum of $30 \%$ land for green open space (RTH). In the midst of meeting this target, the commercial use of public green open space is growing. The situation can potentially reduce the effective area used for the public and affect the quantity of space, as well as the quality of citizen interaction with green open space. This study aims to identify the type and level of public green open space commercialization in Banda Aceh, identify research themes related to green open space commercialization, and formulate a priority list for further study taking into account the conditions of the Covid-19 pandemic. The research was conducted through focus group discussions, field observations, interviews and opinion polls. Preliminary research results in Banda Aceh indicate that commercial activities have the potential to transform public green open space into quasi-public. The presence of multi actors in the management of commercial activities in RTH can be a synergy, but it can also be a contest. The impact of the decrease in visits and the intensity of commercial activities occurred in the early days of the pandemic, but has increased again so that special handling is needed. The focus of research related to the use of green open space as an alternative space for interaction, especially during the pandemic, needs to be formulated with an interdisciplinary approach. The identified priority research agendas are those of applied research characteristics, namely the complete mapping of green open space that is affected by commercial activities and the application of micro zoning to control space use in green open space, including to mitigate the potential spread of the covid-19 outbreak.
\end{abstract}

Keywords: public green open space; commercialization; research agenda; pandemic 
Agustina, Safriana, Ardesir, Nasron / Jurnal Pembangunan Wilayah dan Kota, Vol. 17, No. 2, 2021, 240-250

Doi: https://doi.org/10.14710/pwk.v17i2.36528

\section{PENDAHULUAN}

Penyediaan ruang terbuka hijau (RTH) merupakan kebijakan yang menjadi salah satu andalan dalam membangun kota yang lebih berkelanjutan di berbagai belahan dunia (Tan et al., 2013). Ruang terbuka hijau adalah area memanjang/jalur dan/atau mengelompok, yang penggunaannya lebih bersifat terbuka, tempat tumbuh tanaman, baik yang tumbuh secara alamiah maupun yang sengaja ditanam. RTH publik merupakan ruang terbuka yang dimiliki dan dikelola oleh pemerintah dan digunakan untuk kepentingan masyarakat umum. RTH publik mencakup antara lain taman kota, taman pemakaman umum, serta jalur hijau sepanjang jalan, sungai, dan pantai. Pertumbuhan kawasan perkotaan yang pesat dengan dampak fisik dan sosialnya membuat kebutuhan RTH juga bertambah terutama di kawasan yang berkepadatan penduduk tinggi. Sedangkan RTH privat antara lain adalah kebun halaman rumah/gedung milik masyarakat atau swasta yang ditanami tumbuhan. Undang Undang No.26, 2007 Tentang Penataan Ruang menetapkan target $30 \%$ ketersediaan RTH dalam kota dengan komposisi 20\% RTH publik dan 10\% RTH privat. Angka $30 \%$ tersebut dianggap merupakan ukuran minimal untuk menjamin keseimbangan ekosistem kota seperti keseimbangan sistem hidrologi dan iklim mikro. Proporsi minimal RTH publik sebesar 20\% yang disediakan oleh pemerintah bertujuan agar ketersediaannya dapat lebih terjamin sehingga memungkinkan pemanfaatannya secara luas oleh masyarakat.

Selain berdasarkan kepemilikan, RTH dapat juga diklasifikasikan berdasarkan bentuk, lokasi, aktifitas atau pengelolaan. Pembedaan yang sering digunakan adalah berdasarkan kepemilikan yaitu adanya ruang terbuka publik dan ruang terbuka pribadi atau privat seperti tercantum dalam Undang Undang. Fungsi publik juga dapat didefinisikan secara lebih luas yaitu ruang yang dapat diakses oleh publik walaupun status kepemilikannya adalah privat dan dapat dikategorikan sebagai ruang kuasi-publik. Termasuk dalam kategori ini adalah RTH komunitas dan ruang terbuka dalam kavling lembaga yang secara de facto telah menjalankan fungsi RTH publik dan dalam kasus tertentu bahkan memiliki nilai penting sejarah dalam perannya sebagai RTH. Jika ruang publik formal memiliki peruntukan yang terjamin dengan regulasi, ruang kuasi-publik dengan peran signifikan belum tentu terjamin peruntukannya akan tetap sebagai RTH. Ruang kuasi-publik juga merujuk pada situasi hilangnya kontrol terhadap ruang publik dan fungsinya karena dikelola atau dikuasai oleh privat (Pratt, 2017; Sahito et al., 2020).

Alasan dan manfaat penyediaan RTH dalam berbagai bentuknya pada kawasan perkotaan mencakup misalnya alasan estetis (Zhou \& Parves Rana, 2012), kualitas udara (Vos et al., 2013), kesehatan umum (Shanahan et al., 2016), lokasi untuk melakukan aktifitas fisik (Ord et al., 2013), sebagai perekat sosial (Peters et al., 2010), dapat menurunkan tingkat kriminalitas (Wolfe \& Mennis, 2012), kesejahteraan (Cleary et al., 2017) dan berbagai aspek keberlanjutan (Chiesura, 2004; Ives et al., 2018).

Ketersediaan RTH lazim dilaporkan dalam bentuk agregat persentase RTH terhadap luas wilayah kota. Aspek distribusi, kualitas dan intensitas pemanfaatan ruang seringkali belum dikomunikasikan secara optimal dan kurang mendapat perhatian walaupun justru ada tantangan yang lebih besar dalam pemenuhannya. Saat ini kota Banda Aceh sedang berupaya memenuhi target ketersediaan RTH, namun muncul kegiatan komersial di beberapa RTH yang sekilas dianggap wajar. Komersialisasi bermakna perbuatan menjadikan sesuatu sebagai barang dagangan (KBBI, 2020) atau pengorganisasian dan pengelolaan sesuatu dengan tujuan untuk mendapatkan keuntungan (Cambridge, 2020). Komersialisasi RTH publik dapat didefinisikan sebagai penggunaan ruang dalam RTH berstatus publik atau kuasi-publik untuk berbagai kegiatan komersial. Dampak pemanfaatan ini dapat bersifat positif atau negatif dan sangat tergantung pada jenis, karakter dan intensitas kegiatan komersial yang diwadahi.

Motif komersialisasi antara lain karena adanya tuntutan untuk mendapatkan pemasukan yang digunakan untuk perawatan dan keberlanjutan penyediaan jasa (Smith, 2018) atau semata untuk mendapatkan keuntungan. Walaupun taman kota dan RTH lain tetap berstatus publik namun pertambahan intensitas kegiatan komersil menjadikan RTH sebagai komoditas kapitalis yang dijalankan lembaga swasta (Cooke, 2007). Cooke membahas komersialisasi berskala besar, misalnya dengan pemungutan tiket untuk masuk ke taman kota yang diserahkan sebagian pengelolaannya kepada lembaga komersial. Di sisi lain, komersialisasi ruang publik di Indonesia justru banyak melibatkan sektor informal dengan modal kecil. 
Sektor informal ini terkadang "dikelola" oleh pemerintah, lembaga negara lain atau lembaga informal. Dalam berbagai bentuk dan skala, komersialisasi jelas membawa dampak signifikan pada penyediaan, distribusi dan aksesibilitas taman kota dan RTH lain (Smith, 2018).

Pada masa emergensi kesehatan seperti dalam masa pandemi covid-19, penggunaan RTH dapat menjadi alternatif tempat interaksi yang lebih aman karena memungkinkan penerapan jarak fisik dan interaksi di udara terbuka. Selain itu, rekreasi luar ruang juga memiliki kontribusi penting bagi kesejahteraan secara umum, termasuk untuk kesehatan fisik dan mental. Peningkatan aktifitas fisik di luar ruang semasa pandemi covid telah dilaporkan di berbagai negara termasuk misalnya di Korea (Park et al., 2020). Tetapi perlu diwaspadai bahwa berkumpulnya orang banyak, walaupun di udara terbuka, juga dapat meningkatkan resiko penyebaran di komunitas (Freeman \& Eykelbosh, 2020). Kehadiran aktifitas komersial seperti kios makanan menjadikan bagian RTH sebagai lokasi rekreasi pasif dimana pengunjung cenderung menetap/berkumpul dan dapat menambah resiko penularan. Bagaimana mengoptimalkan peran RTH di tengah pandemi dengan tetap mengedepankan upaya pengendalian wabah perlu dikaji dalam konteks sosial budaya setempat karena tiap daerah mungkin memiliki ciri khas penggunaan RTH tersendiri.

Kota Banda Aceh dilaporkan memiliki $13 \%$ RTH publik (Antara, 2019). Walaupun angka ini masih jauh dari syarat 20\% RTH publik yang disyaratkan Undang Undang, komitmen Pemerintah Kota untuk mencapai target tersebut cukup terbaca melalui berbagai program yang dikomunikasikan melalui aksi di lapangan dan publikasi di media massa. Banda Aceh juga telah berpartisipasi dalam program kota hijau. Peningkatan jumlah taman kota juga nampak di kawasan yang memiliki kepadatan lebih rendah dan peningkatan jalur hijau di kawasan yang lebih padat. Pendekatan yang dilakukan pemerintah masih mengedepankan target total alokasi lahan dan pendekatan estetika pertamanan. Pendekatan pengadaan dan pengelolaan belum cukup mengintegrasikan informasi dari perkembangan riset yang cukup pesat untuk berbagai aspek pengelolaan RTH seperti pengoptimalan distribusi, akses, biodiversitas, optimalisasi fungsi ekologis, sistem jejaring atau aspek lintas disiplin yang lain. Penyediaan aktifitas komersial juga masih didekati dengan pertimbangan ekonomi semata tanpa mempertimbangkan efek jangka panjangnya. Ketika terjadi pandemi covid 19, pengelolaan RTH juga terdampak. Situasi semacam ini tidak memiliki preseden dan memerlukan kerjasama dalam penanganannya, termasuk dalam agenda riset untuk menyediakan informasi ilmiah bagi pengambilan keputusan dalam pengelolaan RTH.

\section{DATA DAN METODE}

Penelitian dilakukan dengan beberapa metode yaitu kajian literatur, diskusi kelompok terarah, observasi lapangan, wawancara serta penjaringan pendapat kelompok pemangku kepentingan. Serangkaian diskusi dilakukan baik dengan anggota tim peneliti maupun dengan narasumber terkait. Observasi lapangan dilakukan pada beberapa RTH kemudian dilanjutkan dengan mengkaji lebih jauh dua lokasi yang merupakan RTH publik utama dan bersejarah di kawasan pusat kota yaitu Blang Padang (BP) dan Taman Sari (TS). Pada dua lokasi ini tampak nyata konsentrasi kegiatan komersial dan pengunjung untuk rekreasi ruang luar terutama pada akhir pekan. Wawancara tidak terstruktur dengan pengunjung dan warga yang menjalankan aktifitas komersial dilakukan untuk mendapatkan gambaran tentang alasan kunjungan, durasi, retribusi, latar belakang sosial budaya, dan kondisi terkini terkait dampak pandemi. Wawancara juga dilakukan dengan akademisi dan perwakilan pemerintah. Kegiatan di lapangan dilakukan dengan menerapkan protokol kesehatan, sedangkan diskusi dan wawancara dengan pelaku kepentingan lain dilaksanakan hampir sepenuhnya dengan sistem dalam jaringan.

Blang Padang (BP) merupakan ruang terbuka yang terluas di pusat kota Banda Aceh (sekitar 8 ha). Saat ini Blang Padang berada di bawah pengelolaan Tentara Nasional Indonesia (TNI) namun status kepemilikannya sempat beberapa kali diperdebatkan, apakah menjadi kewenangan pemerintah Aceh ataukah TNI (Juli, 2018).

Taman Sari (TS) dengan luas sekitar 2 hektar terletak pada kawasan yang sama dengan BP di pusat kota, juga berdekatan dengan Kawasan Mesjid Raya yang merupakan landmark utama di kota Banda Aceh. Taman sari merupakan bagian dari Taman Raja Raja (Bustanussalatin) yaitu taman Kerajaan Aceh yang saat 
Agustina, Safriana, Ardesir, Nasron / Jurnal Pembangunan Wilayah dan Kota, Vol. 17, No. 2, 2021, 240-250

Doi: https://doi.org/10.14710/pwk.v17i2.36528

ini batas aslinya sudah tidak terlihat lagi. Penambahan berbagai fasilitas permanen yang mengurangi luas ruang terbuka di kawasan ini sempat menimbulkan polemik seperti saat pembangunan fasilitas panggung permanen (Agustina, 2018). Taman Sari kini dikelola oleh pemerintah kota Banda Aceh. Kedua RTH bersejarah ini berada di kawasan yang didominasi fungsi perkantoran dan komersial. Upacara hari-hari besar tingkat daerah dan berbagai acara kerap diadakan di Blang Padang dan Taman Sari.

\section{HASIL DAN PEMBAHASAN}

\subsection{Jenis dan Intensitas Kegiatan Komersial di Ruang Terbuka Hijau Publik Kota Banda Aceh}

Pengamatan pada beberapa RTH publik di Banda Aceh menunjukkan bahwa terdapat berbagai jenis kegiatan komersial. Lokasi RTH dan beberapa contoh aktifitas komersial dapat dilihat dalam Gambar 1. Kegiatan komersial ini memberi fasilitas dan kenyamanan bagi warga yang berkunjung namun juga memiliki dampak berupa keramaian, penutupan akses pandang ataupun akumulasi sampah. Kegiatan komersial yang diobservasi sangat bervariasi dan terdistribusi di berbagai tempat seperti taman kota, sempadan sungai dan pantai serta jalur hijau. Bentuk dan ukuran juga bervariasi, mulai dari bangunan permanen berukuran besar sampai tempelan poster dan spanduk di pohon.

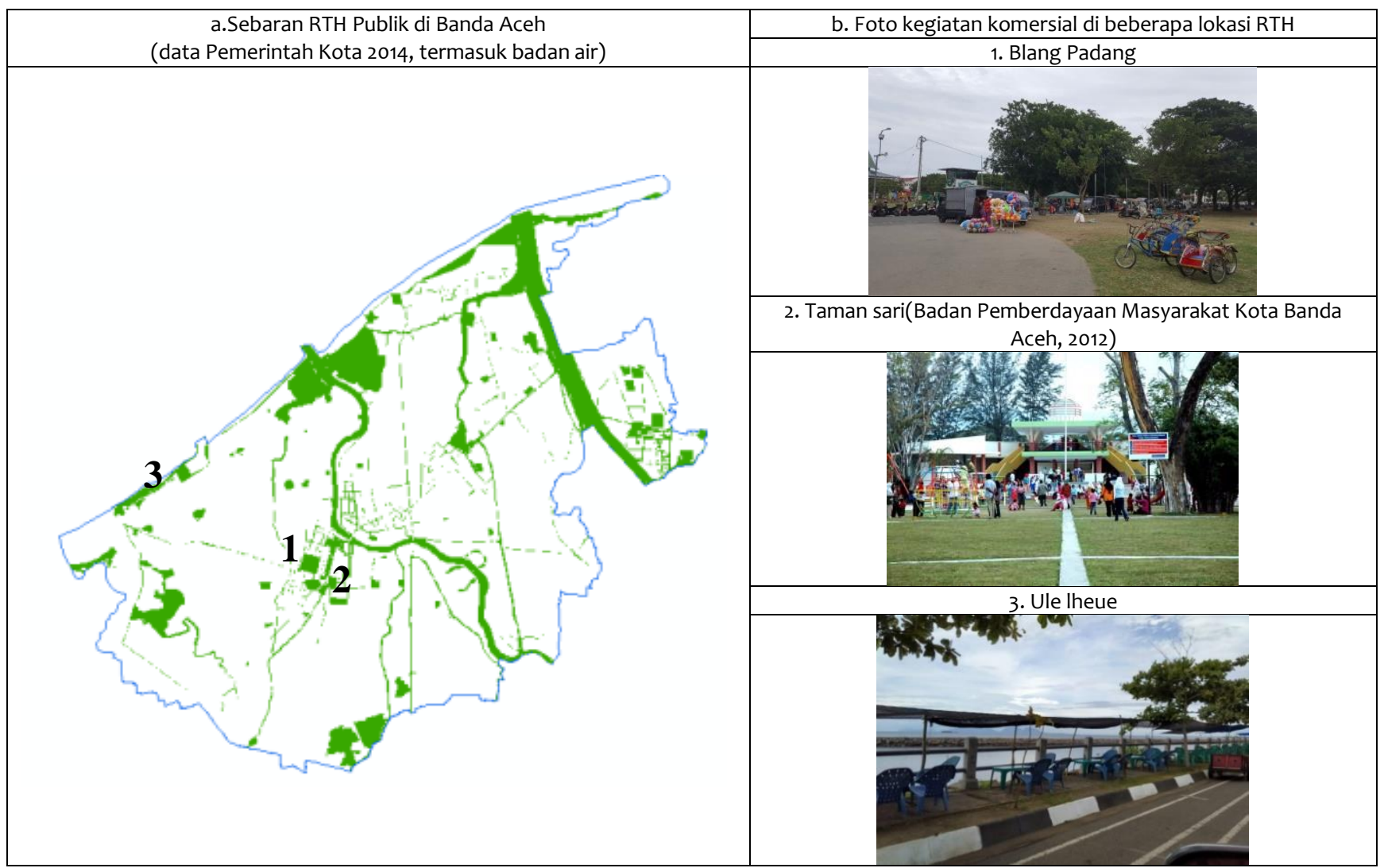

Gambar 1. Sebaran RTH dan contoh aktifitas komersial di berbagai RTH Publik di Banda Aceh

Berbagai aktifitas komersial yang ada dapat dikategorikan berdasarkan karakternya. Pengelompokan semacam ini dapat membantu pengendalian intensitas kegiatan (Tabel 1). Fenomena aktifitas komersial dalam RTH terkait erat dengan maraknya aktifitas komersial di fasilitas publik lainnya seperti di trotoar, bahkan pada badan jalan. Kondisi ini disebabkan antara lain karena lemahnya penegakan hukum dalam pengendalian pemanfaatan ruang dan tidak tersedianya pusat kegiatan komersial yang memadai. Terkonsentrasinya kegiatan komersial pada dua RTH utama yang terdapat di kawasan pusat kota 
Banda Aceh yaitu Lapangan Blang Padang dan Taman Sari patut dikaji lebih lanjut karena potensi terjadinya Ionjakan komersialisasi nampak jelas dan belum tersedianya peraturan untuk memastikan bahwa kegiatan yang memungkinkan interaksi pasif dengan alam dapat tetap berlangsung tanpa adanya distraksi yang berlebihan dari intensitas kegiatan komersial. Ditambah lagi kedua lokasi ini juga memiliki luas terbatas di tengah kawasan yang relatif padat.

Tabel 1. Beberapa pengelompokan tipe kegiatan komersial di RTH Publik

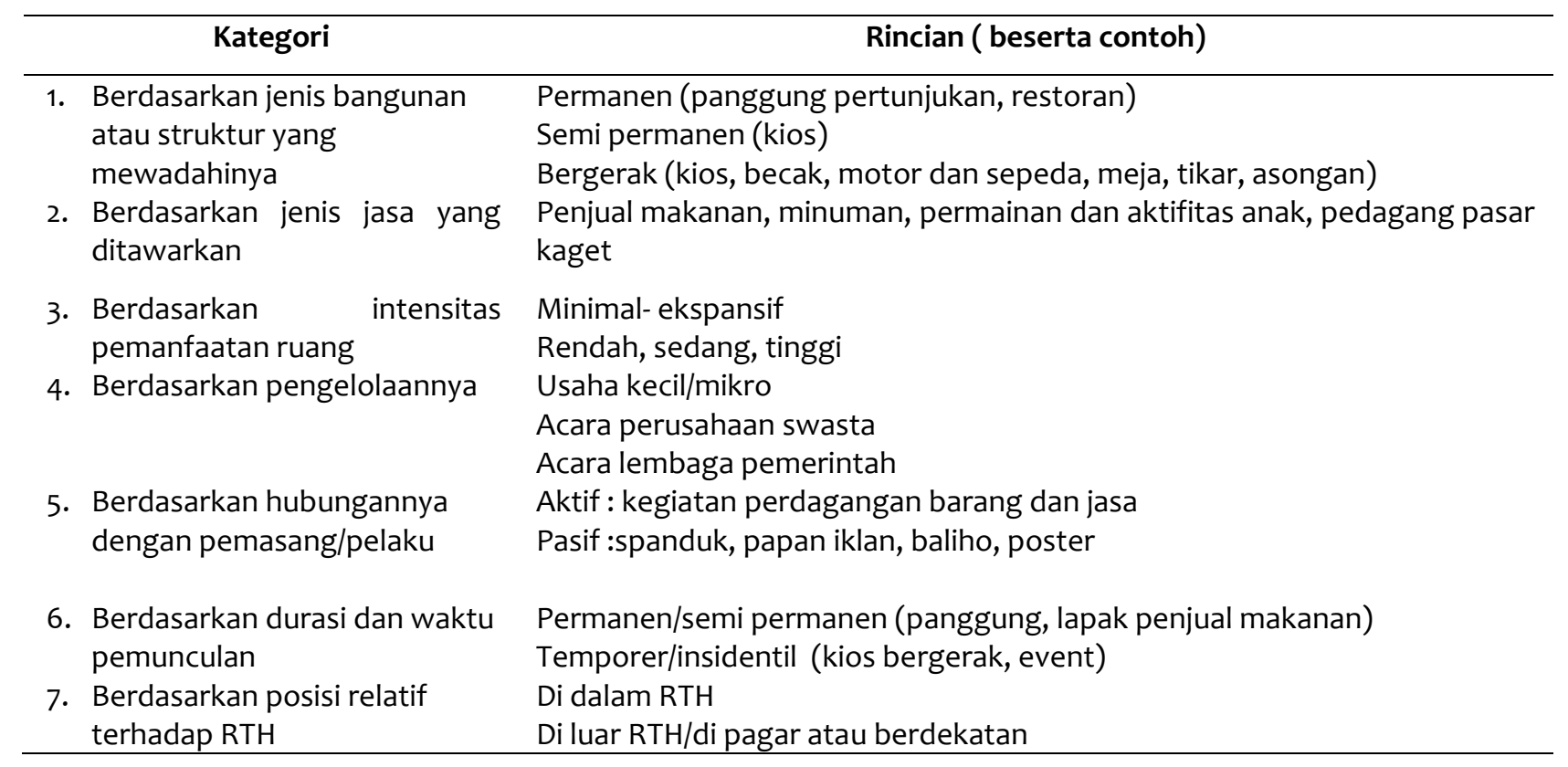

Kajian terhadap citra satelit melalui aplikasi Google Earth Pro (Google LLC., 2020) dalam rentang waktu 2004-2020 pada kedua RTH utama menunjukkan bahwa ada peningkatan luas tajuk pohon namun disertai pula dengan meningkatnya intensitas pemanfaatan ruang mikro dalam kedua lokasi tersebut berupa bertambahnya bangunan permanen dan perkerasan.

Berdasarkan analisis awal, intensitas aktifitas komersial di BP dan TS dapat dikelompokkan menjadi tiga yaitu intensitas tinggi, sedang dan rendah (Gambar 2). Ruang dengan intensitas komersial tinggi diisi oleh struktur permanen atau semi permanen dengan fungsi sepenuhnya komersial atau sebagian komersial. Termasuk dalam ketegori ini adalah bangunan restoran, gedung pertunjukan, lapak semi permanen yang menetap. Intensitas sedang adalah lapak bergerak, gelaran, asongan yang aktif pada waktu tertentu saja dalam sehari sehingga ada jeda waktu dimana RTH dapat digunakan tanpa adanya aktifitas komersial tersebut. Sedangkan zona intensitas rendah adalah zona RTH yang hanya sesekali menerima imbas aktifitas dari zona lain misalnya zona yang dijelajahi permainan mobil anak atau jalur yang dilalui pedagang asongan yang tidak mangkal di satu tempat. Berdasarkan observasi lapangan terlihat bahwa di BP dan TS tidak ada lagi zona yang bebas dari kegiatan komersial pada jam dimana RTH biasa digunakan.

Intensitas komersialisasi pada tahap demikian memerlukan kajian lebih lanjut mengingat salah satu fungsi RTH di pusat kota adalah menjadi penyeimbang bagi kegiatan lain yang berintensitas tinggi, selain tentunya peran ekologisnya misalnya sebagai paru-paru kota atau mitigasi efek pulau panas (Li \& Zhou, 2019). Penelitian terdahulu terhadap pengunjung RTH di sempadan Sungai Krueng Aceh menunjukkan bahwa salah satu hal yang menarik bagi pengunjung adalah ketenangan air yang mengalir, yang menunjukkan bahwa fungsi esensi RTH yaitu fungsi alamiahnya adalah yang menjadi prioritas (Agustina \& Gani, 2010). Persepsi pengunjung RTH saat ini juga perlu dikaji untuk memberi arahan strategis pengelolaan RTH ke depan, khususnya dalam konteks pandemi. Dampak tiap jenis aktifitas juga perlu dipahami dengan 
Agustina, Safriana, Ardesir, Nasron / Jurnal Pembangunan Wilayah dan Kota, Vol. 17, No. 2, 2021, 240-250 Doi: https://doi.org/10.14710/pwk.v17i2.36528

lebih baik. Termasuk dampak cakupan wilayah secara spasial (Gambar 3) ataupun dampak lain seperti dampak kebisingan atau visual.

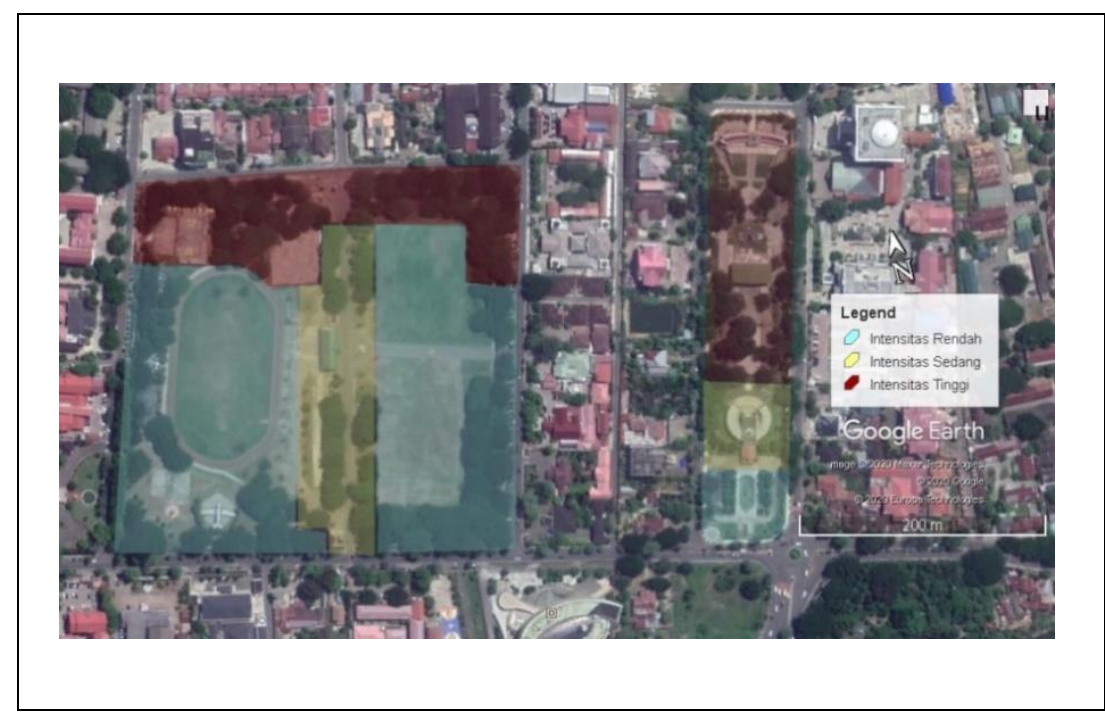

Gambar 2. Zona eksisting di RTH Utama berdasarkan 3 hirarki intensitas

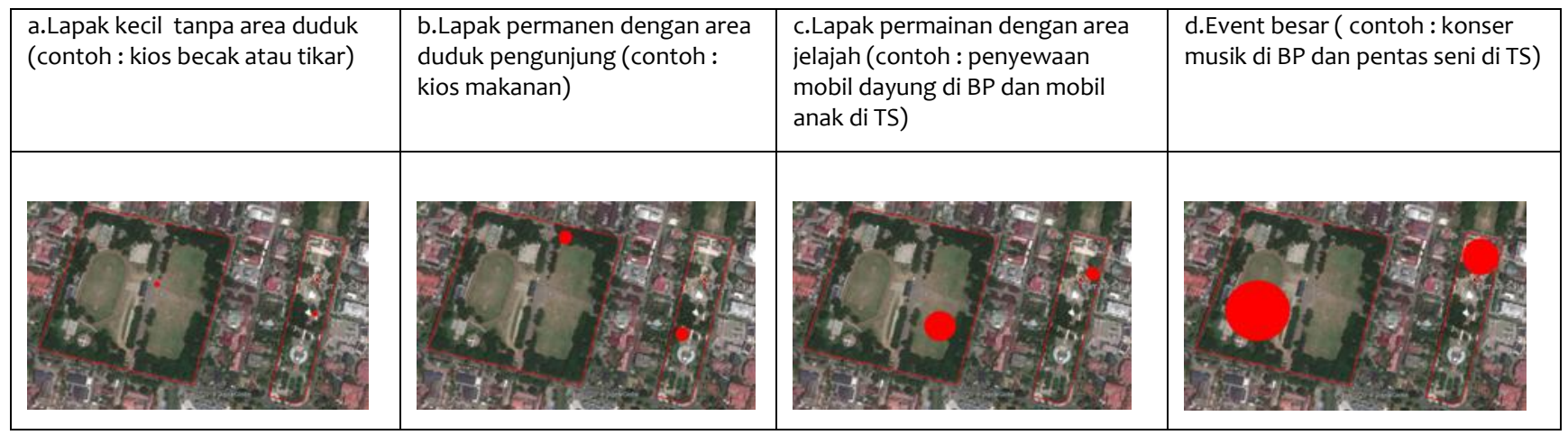

Gambar 3. Simulasi tipologi cakupan ruang beberapa jenis aktifitas pada kedua RTH

Penyediaan lapak semi permanen di BP mulai meningkat pada masa rehabilitasi dan rekonstruksi pasca tsunami Aceh. Dinamika ini diduga turut dipengaruhi oleh tercapainya perdamaian di Aceh setelah lama mengalami konflik militer. Situasi ini terus berlangsung sampai terhenti parsial setelah diberlakukannya Pembatasan Sosial Berskala Besar (PSBB) karena merebaknya covid-19 (kumparan.com, 2020). Data Google Mobility Index (Google LLC, 2020) semasa pandemi menunjukkan trend menurunnya aktifitas warga Indonesia pada awal pandemi namun kemudian kembali meningkat walaupun belum mencapai kondisi normal. Untuk Aceh, data pada periode Oktober-November 2020 juga masih menunjukkan aktifitas di bawah normal pada lokasi yang diklasifikasikan sebagai "park" atau ruang terbuka di Aceh (Gambar 4). Pengamatan dan wawancara dengan pelaku kegiatan komersial serta pengunjung di beberapa lokasi RTH mengonfirmasi bahwa trend kunjungan mulai meningkat kembali walaupun pandemi belum berakhir. 


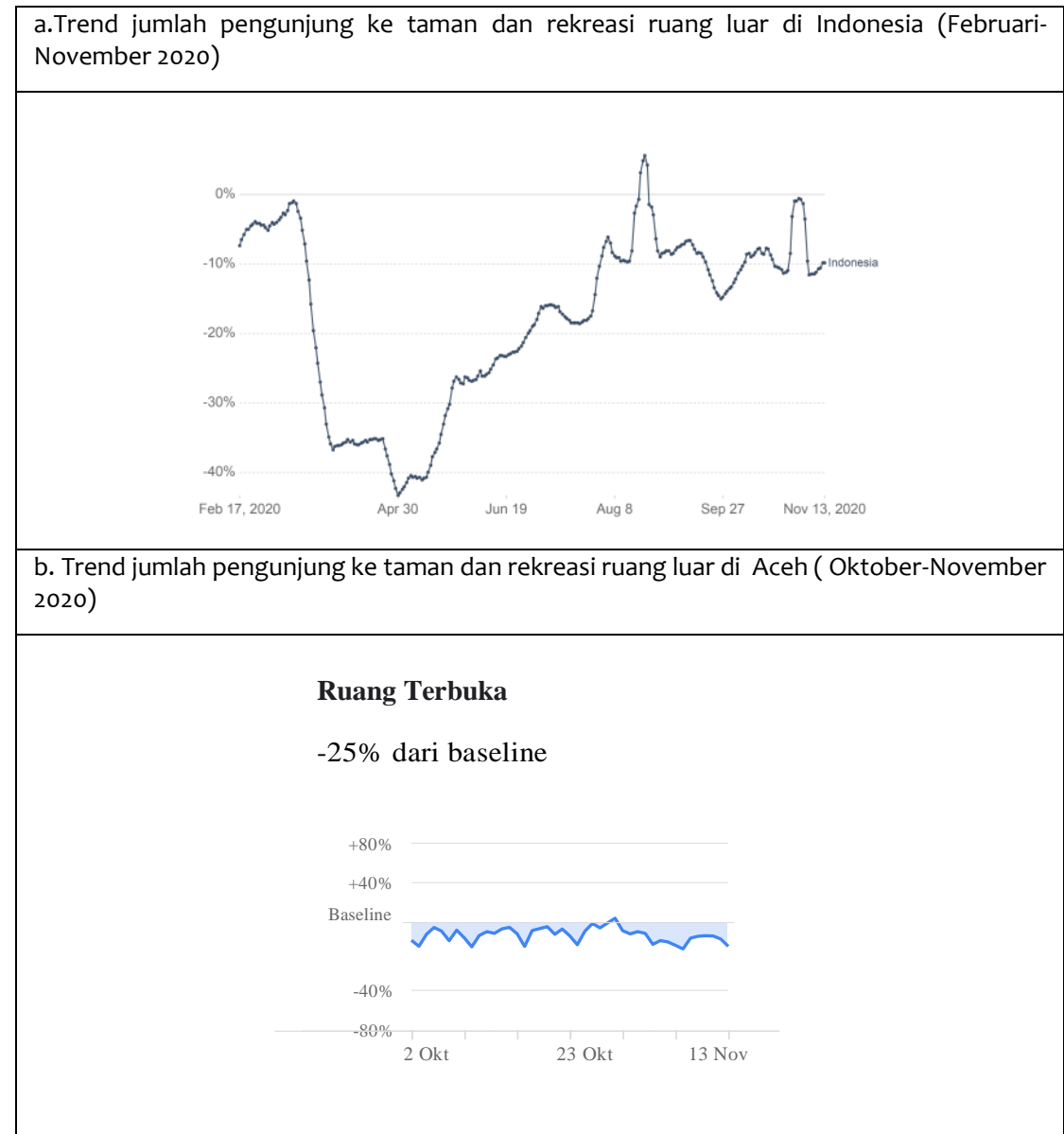

Sumber: Google LLC, 2020

Gambar 4. Trend jumlah pengunjung ke taman dan rekreasi ruang luar di Indonesia dan Aceh dari data Google Mobility

Asosiasi positif antara keragaman guna lahan pada level lingkungan atau bagian wilayah kota dengan bertambahnya intensitas aktifitas warga berjalan kaki atau melakukan aktifitas fisik lain kerap dilaporkan (Fry et al., 2021). Ragam kegiatan aktifitas komersial pada lahan terbatas RTH tidak dapat disamakan dengan ragam guna lahan yang mencakup juga fungsi lain selain fungsi komersial pada level kawasan. Kehadiran fungsi komersial dalam RTH sering menjadi dilema karena memiliki dampat positif dan negatif bagi RTH.

\subsection{Tema Riset yang Terkait dengan Komersialisasi RTH dalam Kerangka Studi Lintas Disiplin}

Berdasarkan kajian literatur, observasi lapangan, wawancara dan diskusi kelompok terarah, diidentifikasi beberapa agenda riset terkait RTH publik terutama dalam kerangka munculnya komersialisasi dan situasi pandemi. Usulan agenda riset ini disusun berdasarkan konteks kota Banda Aceh, namun terbuka peluang untuk menjadikannya pembanding bagi kota lain. Proses identifikasi dilakukan dengan kerangka berpikir lintas disiplin. Pengelompokan bersifat longgar dan dilakukan untuk memudahkan pembahasan dan perujukan. Daftar agenda riset ini kemudian diedarkan secara daring kepada akademisi peneliti isu RTH $(\mathrm{n}=17$, terdiri atas 11 perempuan dan 6 laki-laki) dari 3 universitas di Banda Aceh (Universitas Syiah Kuala, Universitas Islam Negeri Ar-Raniry dan Universitas Muhammadiyah Banda Aceh), juga kepada praktisi serta pejabat pemerintah yang menangani pengelolaan RTH. Mereka diminta untuk memberikan pembobotan/skala prioritas dengan nilai 1-5 (sangat tidak penting-sangat penting). 
Agustina, Safriana, Ardesir, Nasron / Jurnal Pembangunan Wilayah dan Kota, Vol. 17, No. 2, 2021, 240-250 Doi: https://doi.org/10.14710/pwk.v17i2.36528

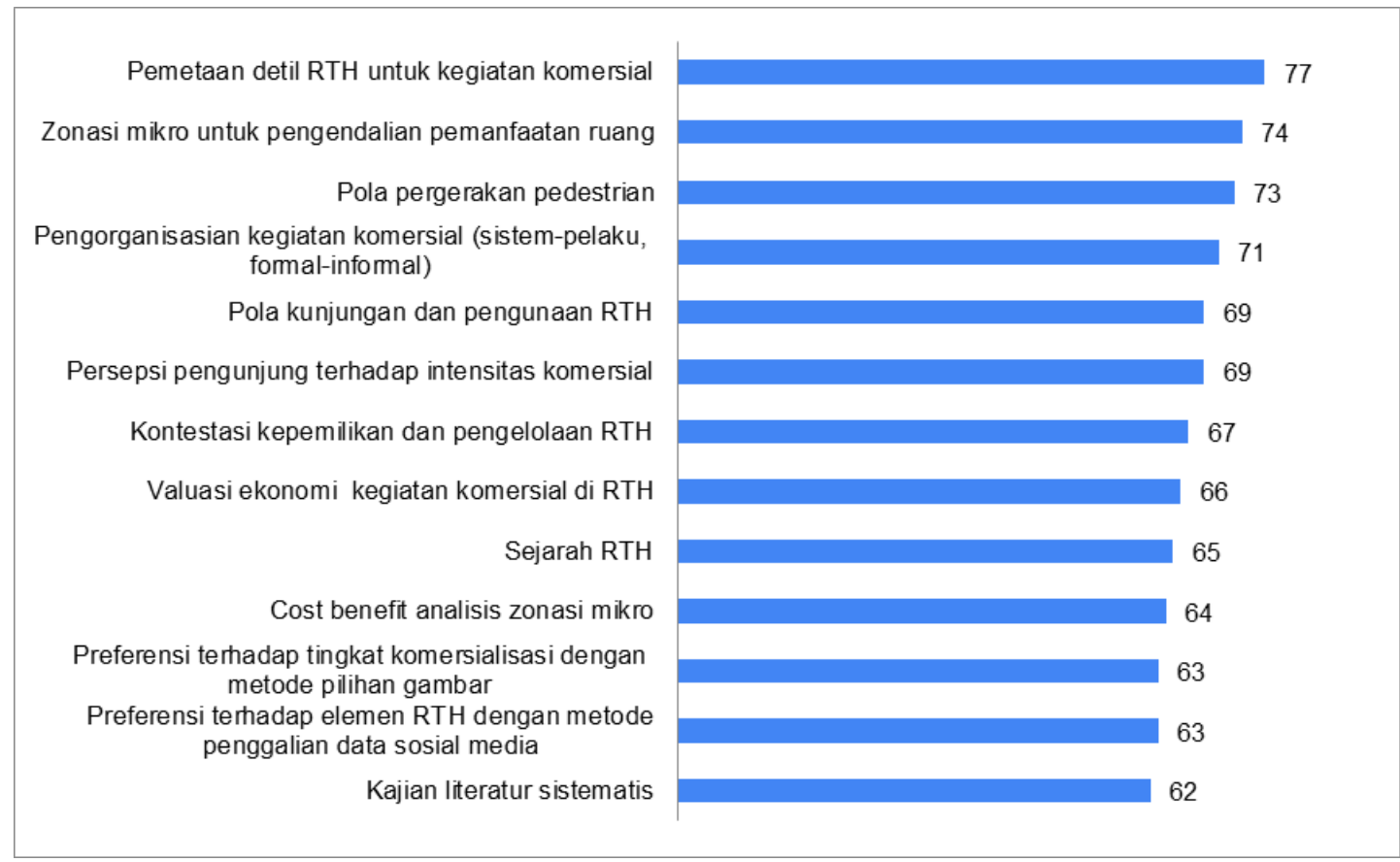

Gambar 5. Prioritas Tema Riset yang Terkait Dengan Komersialisasi RTH (capaian skor dari maksimal 85)

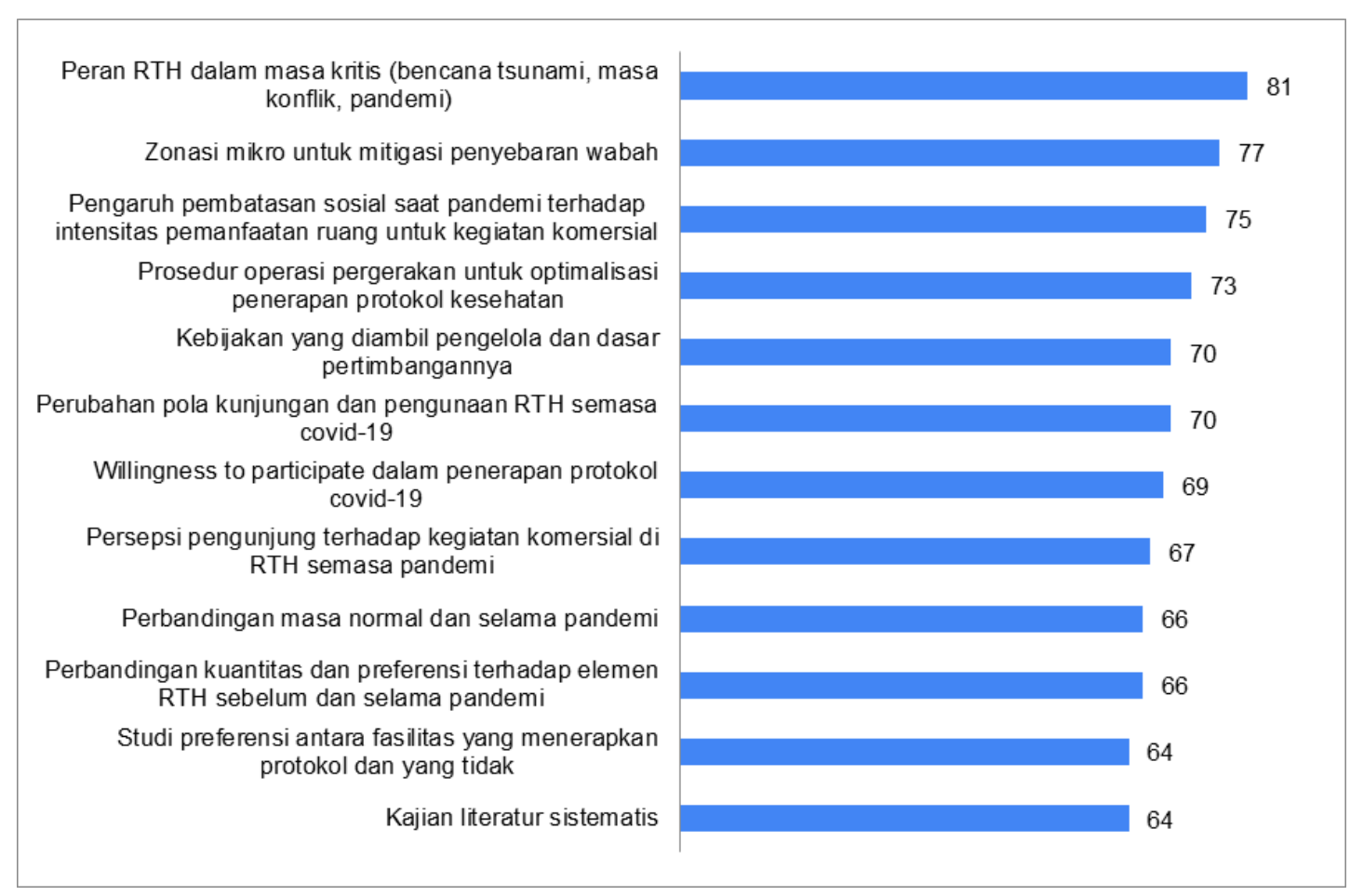

Gambar 6. Prioritas Tema Riset yang Terkait Dengan Komersialisasi RTH dalam Masa Pandemi (capaian skor dari maksimal 85)

Hasil penjaringan pendapat menunjukkan bahwa agenda riset komersialisasi RTH yang dianggap penting adalah pemetaan rinci cakupan dan dampak kegiatan komersial dalam RTH publik, diikuti dengan mengkaji penerapan zonasi mikro untuk pengendalian pemanfaatan ruang dalam RTH (selengkapnya dalam Gambar 5). Penggalangan pendapat juga dilakukan terhadap agenda riset terkait komersialisasi RTH semasa 
pandemi. Hasilnya menunjukkan bahwa kajian peran RTH dalam situasi kritis termasuk pandemi menjadi prioritas, diikuti oleh zonasi mikro untuk mitigasi penyebaran wabah (Gambar 6).

Kedua hasil tentang agenda riset prioritas menunjukkan kebutuhan terhadap riset terapan atau yang berorientasi aksi, tentunya dengan harapan agar dapat segera diterapkan dibandingkan dengan kajian yang lebih bersifat teoritis. Munculnya agenda prioritas ini membuka peluang sinergi antar lembaga terkait dan alokasi anggaran serta sumber daya yang lebih tepat sasaran (Babashahi et al., 2021). Agenda riset prioritas ini juga sejalan dengan meningkatnya kembali kunjungan ke ruang terbuka hijau selama pandemi dan untuk memperkuat peran yang dijalankan RTH untuk ketahanan kota dalam menghadapi pandemi (Venter et al., 2020).

\section{KESIMPULAN}

Penelitian awal ini telah mengidentifikasi pengelompokan aktifitas komersial berdasarkan beberapa karakter kegiatan. Pengelompokan ini diharapkan dapat menjadi dasar dalam pengelolaan pemanfaatan ruang dan membantu menentukan target sasaran program ataupun pelingkupan riset. Salah satu temuan awal yang patut mendapatkan prioritas penanganan atau tindak lanjut adalah memudarnya karakter publik pada dua RTH utama yang telah sepenuhnya mendapat intervensi komersial. Tidak ada lagi ruang yang bebas dari kegiatan komersial. Hal ini sekilas nampaknya diterima oleh warga dan pengunjung, namun kondisi ini perlu mendapat kajian lebih lanjut. Keberadaan kesempatan untuk berinteraksi dengan alam secara lebih intensif melalui RTH lain termasuk RTH privat mungkin membuka ruang penerimaan kondisi tersebut. Di sisi lain, untuk menjamin optimalnya peran RTH untuk diakses bukan hanya oleh publik tetapi juga untuk menghadirkan keanekaragaman hayati di tengah pusat kota maka perlu dipertimbangkan untuk menyediakan zona yang bebas sepenuhnya dari aktifitas komersial yang menunjang peran RTH untuk menjaga biodiversitas kota.

Peluang lain yang dapat ditindaklanjuti adalah membuka akses dari RTH utama ke jejaring RTH lain terutama yang berdekatan, dengan membangun linkage antara beberapa RTH di pusat kota. Kondisi saat ini masih terputus dan berdiri sendiri. Membangun jaringan RTH membuka kesempatan bertambahnya ruang dimana intensitas komersial sangat dibatasi atau tidak diperbolehkan sama sekali. Jejaring demikian juga menyediakan ruang yang lebih luas untuk interaksi sosial pada masa pandemi sehingga tidak terkonsentrasi di dua RTH utama.

Kajian awal ini juga telah menginventarisir beberapa tema riset. Pemaparan tema riset diharapkan dapat membuka bukan hanya ruang diskusi namun juga ruang kerjasama riset untuk memberikan informasi ilmiah bagi pengambilan keputusan tentang pengelolaan RTH.

\section{PERNYATAAN RESMI}

Terima kasih kepada Asosiasi Sekolah Perencanaan Indonesia (ASPI) yang telah memberikan kesempatan bagi tim penulis untuk menyampaikan versi awal tulisan ini dalam Seminar Nasional ASPI 2020 bertema "Penataan Ruang Inklusif di Era Pandemi Covid 19" yang dilaksanakan secara daring dengan tuan rumah Universitas Syiah Kuala, Banda Aceh pada bulan November 2020. Kami juga berterima kasih kepada seluruh responden yang telah berpartisipasi dalam wawancara dan penjaringan pendapat.

\section{DAFTAR PUSTAKA}

Agustina, S. (2018). Demam Panggung (Paradigma Pengelolaan RTH Kota Banda Aceh). Retrieved from Serambinews website: https://aceh.tribunnews.com/2018/08/08/demam-panggung

Agustina, S., \& Gani, A. (2010). Returning The Spirited Away Krueng Aceh River : Urban Design Approach To Promote For River Sustainability. Paper presented at the International Conference On Sustainable Future For Human Security (SUSTAIN), Kyoto. 
Agustina, Safriana, Ardesir, Nasron / Jurnal Pembangunan Wilayah dan Kota, Vol. 17, No. 2, 2021, 240-250

Doi: https://doi.org/10.14710/pwk.v17i2.36528

Antara. (2019, 4 February 2019). Ruang terbuka hijau di Aceh diupayakan penuhi 20 persen, Antaranews (Kantor Berita Antara). Retrieved from https://www.antaranews.com/berita/794769/ruang-terbuka-hijau-di-acehdiupayakan-penuhi-20-persen

Babashahi, S., Hansen, P., \& Sullivan, T. (2021). Creating a priority list of non-communicable diseases to support health research funding decision-making. Health Policy, 125(2), 221-228.

Badan Pemberdayaan Masyarakat Kota Banda Aceh. (2012). Taman Sari Banda Aceh. Banda Aceh Model Kota Madani (Blog BPM Kodya Banda Aceh), 2020(15 November). https://bandaacehkotamadani.wordpress.com/2012/08/23/taman-sari-banda-aceh/

Cambridge. (2020). Commercialization. $\quad$ Retrieved $19 \quad$ November, 2020, from (https://dictionary.cambridge.org/dictionary/english/commercialization)

Chiesura, A. (2004). The role of urban parks for the sustainable city. Landscape and Urban Planning, 68(1), 129-138. doi: http://dx.doi.org/10.1016/j.landurbplan.2003.08.003

Cleary, A., Fielding, K. S., Bell, S. L., Murray, Z., \& Roiko, A. (2017). Exploring potential mechanisms involved in the relationship between eudaimonic wellbeing and nature connection. Landscape and Urban Planning, 158, 119128. doi: 10.1016/j.landurbplan.2016.10.003

Cooke, O. (2007). A class approach to municipal privatization: the privatization of New York City's Central Park. International Labor and Working-Class History, 112-132.

Freeman, S., \& Eykelbosh, A. (2020). COVID-19 and outdoor safety: Considerations for use of outdoor recreational spaces. National Collaborating Centre for Environmental Health.

Fry, D., Aaron Hipp, J., Alberico, C., Huang, J.-H., Lovasi, G. S., \& Floyd, M. F. (2021). Land use diversity and park use in New York City. Preventive Medicine Reports, 22, 101321. doi: https://doi.org/10.1016/j.pmedr.2021.101321

Google LLC. (2020). Google COVID-19 Community Mobility Reports

Retrieved November 19, 2020, from https:/www.google.com/covid19/mobility

Ives, C. D., Abson, D. J., von Wehrden, H., Dorninger, C., Klaniecki, K., \& Fischer, J. (2018). Reconnecting with nature for sustainability. Sustainability Science, 13(5), 1389-1397. doi: 10.1007/s11625-018-0542-9

Juli, M. (2018). Lapangan Blang Padang Milik Siapa? https://www.acehtrend.com/2018/05/07/lapangan-blang-padangmilik-siapal

KBBI. (2020). Kamus Besar Bahasa Indonesia (KBBI) online. Retrieved 15 November 2020, from https://kbbi.web.id/komersialisasi

kumparan.com. (2020). Tempat Wisata di Banda Aceh Segera Dibuka Kembali Usai Ditutup karena Corona. Retrieved 18 November, 2020, from https://kumparan.com/acehkini/tempat-wisata-di-banda-aceh-segera-dibukakembali-usai-ditutup-karena-corona-1tZBYvFoFdN

$\mathrm{Li}, \mathrm{X}$., \& Zhou, W. (2019). Optimizing urban greenspace spatial pattern to mitigate urban heat island effects: Extending understanding from local to the city scale. Urban Forestry \& Urban Greening, 41, 255-263.

Ord, K., Mitchell, R., \& Pearce, J. (2013). Is level of neighbourhood green space associated with physical activity in green space? International Journal of Behavioral Nutrition and Physical Activity10; 127.

Park, S., Kim, B., \& Lee, J. (2020). Social Distancing and Outdoor Physical Activity During the COVID-19 Outbreak in South Korea: Implications for Physical Distancing Strategies. Asia Pacific Journal of Public Health, 32(6-7), 360-362.

Peters, K., Elands, B., \& Buijs, A. (2010). Social interactions in urban parks: stimulating social cohesion? Urban Forestry \& Urban Greening, 9(2), 93-100.

Pratt, A. (2017). The rise of the quasi-public space and its consequences for cities and culture. Palgrave Communications, 3(1), 36. doi: 10.1057/s41599-017-0048-6

Sahito, N., Han, H., Nguyen, T. V. T., Kim, I., Hwang, J., \& Jameel, A. (2020). Examining the Quasi-Public Spaces in Commercial Complexes. Sustainability, 12(5), 1830.

Shanahan, D. F., Bush, R., Gaston, K. J., Lin, B. B., Dean, J., Barber, E., \& Fuller, R. A. (2016). Health benefits from nature experiences depend on dose. Scientific Reports, 6, 28551.

Smith, A. (2018). Paying for parks. Ticketed events and the commercialisation of public space. Leisure Studies, 37(5), 533-546.

Tan, P. Y., Wang, J., \& Sia, A. (2013). Perspectives on five decades of the urban greening of Singapore. Cities, 32, 24-32. doi: 10.1016/j.cities.2013.02.001

Venter, Z. S., Barton, D. N., Gundersen, V., Figari, H., \& Nowell, M. (2020). Urban nature in a time of crisis: recreational use of green space increases during the COVID-19 outbreak in Oslo, Norway. Environmental Research Letters, 15(10), 104075. doi: 10.1088/1748-9326/abb396

Vos, P. E., Maiheu, B., Vankerkom, J., \& Janssen, S. (2013). Improving local air quality in cities: to tree or not to tree? Environmental Pollution, 183, 113-122. 
Agustina, Safriana, Ardesir, Nasron / Jurnal Pembangunan Wilayah dan Kota, Vol. 17, No. 2, 2021, 240-250 Doi: https://doi.org/10.14710/pwk.v17i2.36528

Wolfe, M. K., \& Mennis, J. (2012). Does vegetation encourage or suppress urban crime? Evidence from Philadelphia, PA. Landscape and Urban Planning, 108(2-4), 112-122. doi: 10.1016/j.landurbplan.2012.08.006

Zhou, X., \& Parves Rana, M. (2012). Social benefits of urban green space: A conceptual framework of valuation and accessibility measurements. Management of Environmental Quality: An International Journal, 23(2), $173-189$. 